\title{
ECOLOGICAL GROWTH BOUNDARIES
}

\author{
Anna BLUSZCZ \\ Silesian University of Technology
}

\begin{abstract}
:
The trends of the society for the continuous growth, combined with the demographic changes, today have led to the important ecological problems on a global scale, which include, among others: the increased use of non-renewable natural resources, an increase of the greenhouse gas emissions, contamination of soil, water, air and the progressive degradation of ecosystems. In the face of such serious threats the global initiatives of all countries are important to limit the results of the excessive consumption. The aim of the article is to present the methods of measurement of the consumption level of natural resources by the societies and the examination of relationships between the level of development of the societies and the use of resources. The popular measure - the ecological footprint - was used as a measurement method for the consumption of the today's generations in relation to the regenerative possibilities of the natural environment. On the other hand, as the assessment method for the level of development of societies - the Human Development Index (HDI), including three basic areas: the life expectancy, GDP level per capita and education was used. The results of the research indicate that the current trend of the unlimited consumption of the highly developed countries takes place at the expense of the future generations.
\end{abstract}

Key words: ecological footprint, human development index, sustainable development

\section{INTRODUCTION}

The steady growth in demand for energy, climate problems, the exponential tendency of the increase of greenhouse gas emissions, increase in pollution of soils, waters, air and the progressive degradation of ecosystems are the most serious civilisation problems of our generation. Hence, today the following questions are current: Where are we going? What are the limits of economic growth? How to ensure the well-being of current and future generations without degrading the environment?

The presented challenges are the global problems and they cannot be solved by implementing the actions locally, only the cooperation of all countries can bring a result. So, what actions should be taken on a global scale to, on one hand, maintain the development of the society, and on the other, protect natural resources for future generations? This question has no clear answer today, however, the facts suggest one thing, that maintaining the current level of consumption of highly-developed countries at the current growth rate of the population already in near future will lead to the exhaustion and depletion of natural resources, and the environment will lose the natural opportunity to rebuild.

Land resources are divided into renewable and nonrenewable. Renewable resources can be obtained at a rate no faster than the rate of their rebirth without a loss for future generations. In the 90 s of the XX century $20 \%$ of the land biomass production was used to meet the needs of the population in terms of food, fuel, paper. In the first decade of this century, this level rose to $25 \%$, with this trend until the mid-century we will be using more than half of all land biomass.
According to the Organisation of the United Nations for Food and Agriculture, 38\% of the Earth's ice-free surface has been converted to agricultural lands (including $12 \%$ of crops, $26 \%$ pastures). Crops already represent $70 \%$ of the grasslands, $50 \%$ of the savannas and once occupied by forests, and $27 \%$ of tropical areas. From 1985 to 2005 there was a significant expansion of the tropical areas, which has a huge impact on biodiversity, emissions and soil conditions [3].

With the end of the XVIII century, the negative effects of the industrial revolution and the increasing human pressure on Earth were strongly highlighted. The human population is increasing exponentially, while the amount of the available natural resources is limited. Hence numerous initiatives and concepts of scientists, international organisations or global corporations aimed to minimise the human pressure on the natural environment, however, which takes into account the aspects of the society development. The concepts of the socio-economic development and environmental protection are interdependent, and in scientific publications stated functioning under the following names, e.g., ecological development [7], development without destruction [9] or environmentally friendly development [1].

In 1980, the International Union for Conservation of Nature (IUCN) published, in cooperation with World Wildlife Fund (WWF) and United Nations Development Programme (UNDP) a document entitled: "The World Strategy for Nature Conservation" [12]. The report stressed the importance of social and ecological factors in the long-term socio-economic development. It has also become the basis for today's most widely distributed notion in economy, taking into account the environment - the concept of the 
so-called sustainable development. This notion, as the political and environmental pattern, was first used in the Report of the World Commission on Environment and Development (WCED) entitled "Our Common Future from the year of 1987 [10].

The core of the concept is the preservation of regenerative capacity of the natural environment meeting the needs of today's generations, at the same time without limiting the abilities of the future generations to meet their needs.

The aim of the article is the presentation of the relationships between the level of development of societies and the consumption of resources. The Human Development Index (HDI) was used as a method for evaluating the level of development, including three basic areas: life expectancy, GDP level per capita and education. Whereas the Ecological Footprint - as the method for measuring the level of consumption of today's generations with regard to the regenerative capacities of the environment.

\section{ECOLOGICAL FOOTPRINT AS A MEASURE OF THE CON- SUMPTION OF NATURAL RESOURCES BY MAN}

Ecological Footprint, also called the ecological foot trace is one of relatively new measures that allows for the assessment of human pressure on the environment by the size of goods and services consumption. The value of the Ecological Footprint determines the surface of the biologically productive area, which is essential for meeting vital needs of the human population, taking into account the lifestyle [11]. It is measured with the land and sea surface, needed to produce the resources currently used by the mankind and to absorb the pollutants produced by men. The creator of the ecological footprint concept is Prof. Mathis Wackernagel, currently the director of the organisation of Global Footprint Network. In one of the interviews he stated that: "... analysing the global economy in the criteria of the ecological footprint resembles the accounting of our household incomes. We have to know how much we earn and how much we spend, because otherwise it will not be possible to predict the bankruptcy. This simple rule also refers to ecology" [13]. Ecological Footprint identifies six categories of areas measured literally with the unit areas (so-called global hectares), i.e.: agricultural and farm use of the land, forests, fishing areas, urban areas, green areas absorbing carbon dioxide. The ecological footprint shows, above all, to what extent the areas with high industrialisation rely on natural resources located in other parts of the world. For each area we calculate the rate, expressed in area units, in global hectares per person (gha/p).

We cannot forget that only part of the Earth surface is suitable to be live on by man. Only $29,2 \%$ of the planet's surface are land areas $\left(148940000 \mathrm{~km}^{2}\right)$, but the man is not able to live in all conditions. $11 \%$ of the land surface $\left(16383400 \mathrm{~km}^{2}\right)$ are subekumens, which include deserts, areas covered with ice or permafrost, unfit for permanent residence and use [6]. Therefore, the surface which can be inhabited amounts to $132556600 \mathrm{~km}^{2}$ ).

On average, a person needs $2,7 \mathrm{gha} / \mathrm{p}$., to meet his vital needs. Meanwhile, if we divide the production surface of our planet by the number of its inhabitants, it will turn out that there is only 2,1 gha per person. This means that we use more resources than the Earth is able to generate.

Especially in rich countries, highly-developed, there is the excessive and constantly growing consumption (17 tons of raw material per 1 person a year) [2].

EF calculations are regularly published in reports of WWF Living Planet 2012 (LPRB) [14].

Based on the data presented in Figure 1, we can see that the ability for the environmental regeneration is steadily decreasing compared to the increasing human pressure on the environment in the form of consumption of natural resources and production of pollution.

The largest national ecological footprint is found in the USA and China. Each of these countries consumes one-fifth of the Earth's resources. However, while the ecological footprint for a resident of China is an average of $2.1 \mathrm{gha} /$ person, for a resident of the USA - over 9 gha/person.

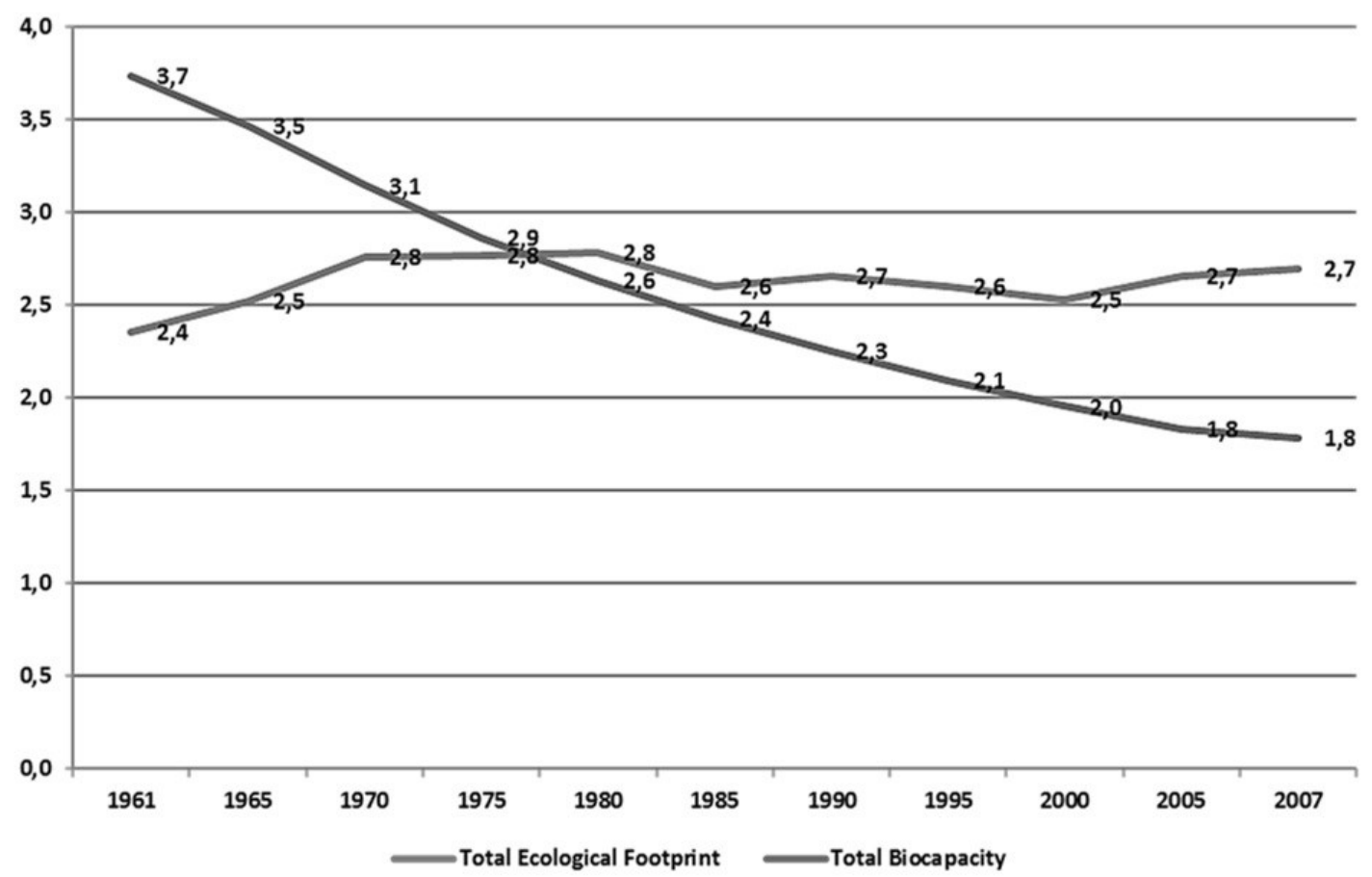


Table 1

Ecological footprint level of the world

\begin{tabular}{|c|c|c|c|c|}
\hline & $\begin{array}{l}\text { Population } \\
\text { (mln) }\end{array}$ & $\begin{array}{c}\text { Ecological Footprint } \\
\text { gha/osobę }\end{array}$ & $\begin{array}{l}\text { Biocapacity } \\
\text { gha/osobę }\end{array}$ & Deficit \\
\hline World & 6671.6 & 2.7 & 1.8 & (0.9) \\
\hline Very highly developed countries & 1031.4 & 6.1 & 3.1 & (3.0) \\
\hline Highly developed countries & 4323.3 & 2.0 & 1.7 & $(0.2)$ \\
\hline Countries with a low level of development & 1303.3 & 1.2 & 1.1 & $(0.1)$ \\
\hline Europa & 730.9 & 4.7 & 2.9 & $(1.8)$ \\
\hline
\end{tabular}

Source: [15].

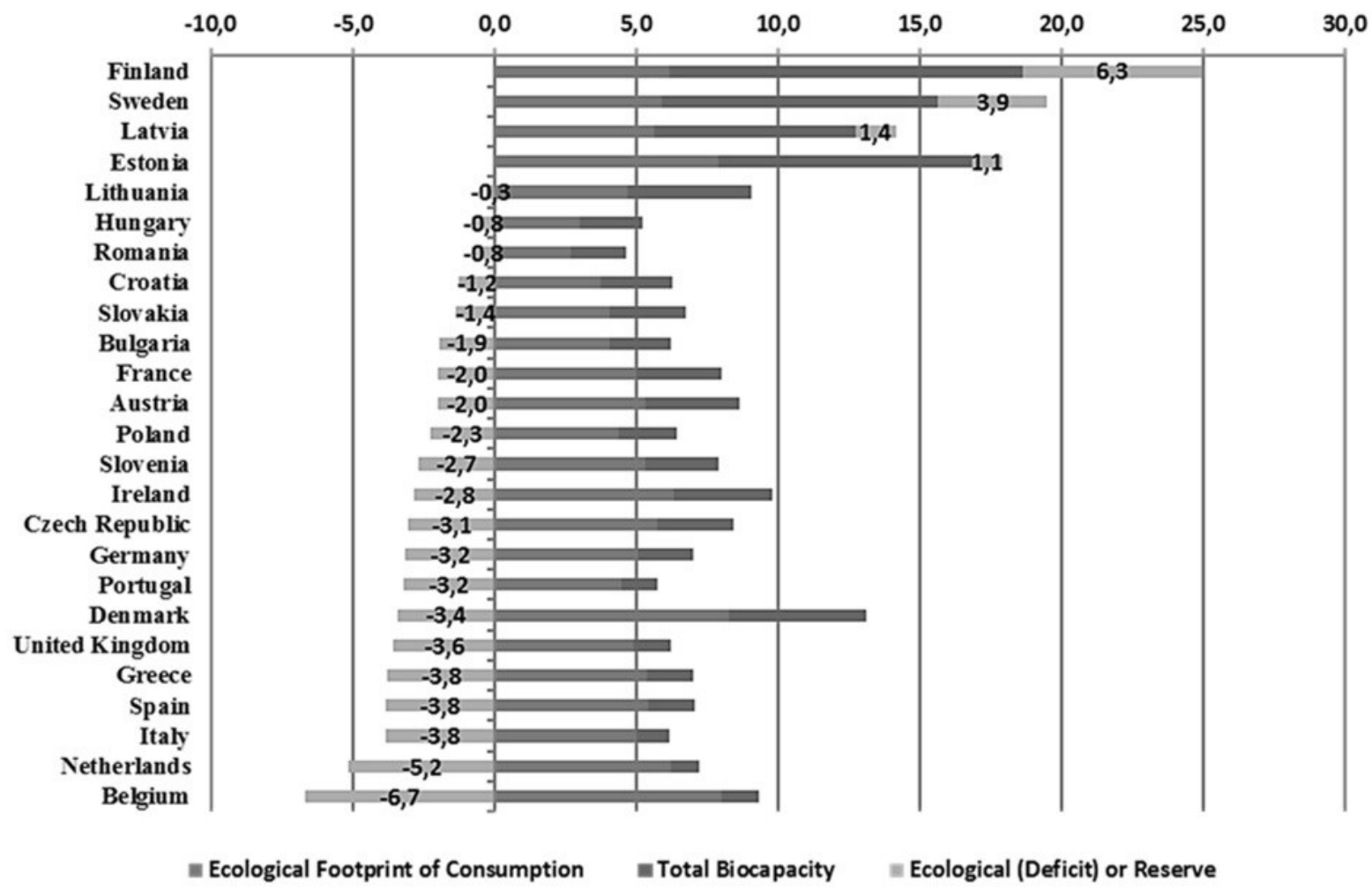

Fig. 2 Global Ecological Footprint

Source: [15].

In contrast, the ecological footprint for a resident of Congo, which has the seventh biological capacity in the world (13.9 gha/person), is only 0.5 gha/person.

Based on the data presented on the Global Footprint Network websites, the examples of estimations for the ecological footprint were presented for the world (Table 1) and the European Union countries (Figure 2).

The currently growing rate of consumption of mineral resources by mankind shows deficit of self-renewal capabilities by the environment and this state of affairs leads to the inevitable depletion of the resources on Earth in the long-term perspective.

Figure 2 presented the estimated ecological deficit or the ecological reserve for the European Union member states (excluding Cyprus and Malta, due to the lack of data).

On the basis of the presented data we can see that only four countries from the 26 surveyed member states have got the ecological reserve, that is, use less resources than their biological ability, these are:

- Finland, for which the ecological footprint was 6.2 gha/person and the biological capability $12.5 \mathrm{gha} /$ person, hence the highest reserve of 6.3 gha/person,
- Sweden, for which the ecological footprint was $5.9 \mathrm{gha} /$ person and the biological capability $9.7 \mathrm{gha} /$ person, hence the highest reserve of 3.9 gha/person,

- Latvia, for which the ecological footprint was $5.6 \mathrm{gha} /$ person and the biological capability $7.1 \mathrm{gha} /$ person, hence the highest reserve of 1.4 gha/person,

- Estonia, for which the ecological footprint was 7.9 gha/person and the biological capability 9 gha/ person, hence the highest reserve of 1.1 gha/person.

Poland belongs to the countries with an ecological deficit, that means that we use more resources than the Polish biological ability. Polish ecological footprint is $4.3 \mathrm{gha} /$ person, and the ekological deficit of Poland is $2.3 \mathrm{gha} /$ person. This means that we use almost two times more than Earth could offer us, if all people used its wealth equally.

Countries with the highest ecological deficit are: Belgium (6.7 gha/person); Netherlands (5.2 gha/person); Spain, Italy and Greece with the deficit at the same level of 3.8 gha/person, Great Britain (3.6 gha/person), Denmark (3.4 gha/person), Germany and Portugal (3.2 gha/person).

The ecological footprint can be calculated individually for each person or a group of people - organisation, society, nation, or for the manufacturer or type of production, such as the production of a specific product. 


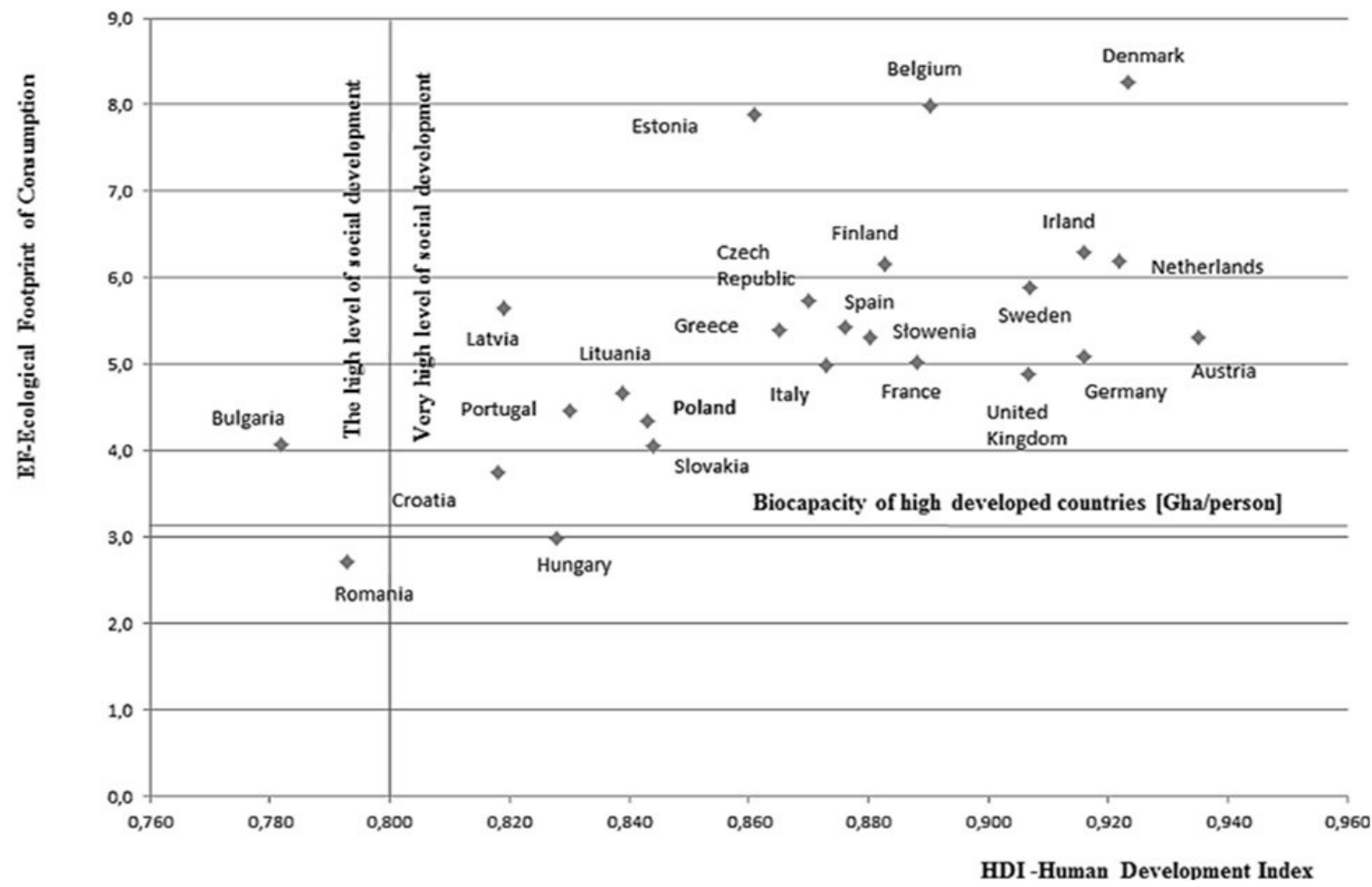

Fig. 3 Relations between Ecological Footprint (EF) and Human Development Index (HDI)

Source: [15].

All consumed biological materials and the whole emission of the produced carbon dioxide in a year are taken into account. For example: the production of $1 \mathrm{~kg}$ of beef emits the same amount of $\mathrm{CO}^{2}$ as driving a car non stop at $50 \mathrm{~km} /$ $\mathrm{h}$ for $250 \mathrm{~km}$. Production of the same portion of meat will absorb the same amount of energy as the 20 watt light bulb for 20 days.

Environmentalists seek to ensure that the ecological footprint was a constantly used measure of economic growth, complementing the traditional indicator of the gross domestic product.

\section{HUMAN DEVELOPMENT INDEX - HDI}

Human Development Index (HDI) is an indicator created by the United Nations Organisations in order to measure development of individual countries taking into account three basic areas: life expectancy, GDP per capita, education. The indicator level is in the range of $<0.1>$. The calculations started in 1990 and are published annually in the form of country rankings. Poland was 35 in the ranking in 2013, among 187 countries included in the evaluation.

According to the studies presented on the websites of Global Footprint Network, the higher the national income, the higher the ecological footprint. The relationship between the level of Human Development Index (HDI) and the level of the footprint was presented in Figure 3.

In the long term, sustainable development can be achieved only if the countries meet two criteria at the same time: ecological footprint will be smaller than 1.8 gha per capita, and the human development index (HDI) will be higher than 0.8 .

Environmentalists seek to ensure that the ecological footprint is a constantly used measure of economic development, complementing the traditional indicator of gross domestic product.

\section{SUMMARY AND CONCLUSIONS}

The socio-economic development is highly dependent on access to mineral and energy resources.

The fact that $80 \%$ of the world population lives in countries, where more resources are consumed than their ability to reconstruct them within these countries means that the consequences of this consumption will be moved to the next generations. If everyone on Earth lived at such a high level of consumption, humanity would need 5 planets like Earth to live [5].

The system of connections and relationships between the standard of living of the society, economy and the state of the environment determines one possible direction of further existence, that is sustainable development. The consumption of natural resources must take place considering the principles of rational management at the level of the biological ability of the environment. On the other hand, in industry, all pro-ecological initiatives are necessary, which aim is to minimise the negative results of the effects on the environment [8]. Therefore, popularisation of the measurement methods for the level of natural resources consumption, among others, in the form of the ecological footprint, should stimulate the responsibility of the countries and each citizen for his lifestyle.

\section{REFERENCES}

[1] L.S. David. L. Duckstein. "Multicriterion ranking of alternative long-range water resources systems", Water Resources Bulletin, vol. 12, pp. 731-754, 1976.

[2] J. Dubiński. M. Turek. „Szanse i zagrożenia rozwoju górnictwa węgla kamiennego w Polsce". in Wiadomości Górnicze nr 11, pp. 626-633, 2012.

[3] J.A. Foley et al. (2011, Oct). "Solutions for a cultivated planet". Nature, [On-line]. vol. 478, pp. 337-342. Available:

http://www.soest.hawaii.edu/oceanography/courses/ OCN310_2/Fall14/files/essay4/foley.pdf [Jun.1, 2015] 
[4] S. Burns. M. Wackernagel. "Footprint-Annual Report 2012". Global Footprint Network. Internet: http:// www.footprintnetwork.org/images/ article uploads/2012 Annual_Report.pdf, 2012 [Jun. 1,2015 ]

[5] L. Kłos. „Ślad ekologiczny jako nieekonomiczny miernik jakości życia społeczeństwa". Available: http://www.ue.katowice.pl/fileadmin/_migrated/ con-

tent_uploads/6_L.Klos_Slad_ekologiczny_jako_nieek onomiczny_miernik....pdf [June. 15, 2015]

[6] J. Makowski. Geografia fizyczna świata. Warszawa PWN, 2007, s. 302.

[7] I. Sachs. "Eco-development: a definition", Ambio, vol. 8, no, 2-3, pp. 111-113, 1979.

[8] J. Słonimiec. P. Szatkowska. N. Stępień. J. Urban. S. Dobosz. G. Biernacki. JI. Han Yeon. „Stan realizacji celów zintegrowanej polityki produktowej w Polsce na tle pozostałych krajów Unii Europejskiej". in Management System in Production Engineering No 4(20), 2015. DOI 10.12914/MSPE-01-04-2015

[9] M.K. Tolba. Development without Destruction: Evolving Environmental Perceptions. Dublin: Tycooly Publishing, 1976.
[10] WCED, Our Common Future, London: Oxford University Press, 1987.

[11] W. Wilczyńska-Michalik. K. Świder. „Założenia koncepcji Ekologicznego Śladu i przykłady obliczeń dla dużych miast". Studia Geographica I, pp. 103-125, 2010.

[12] World Conservation Strategy. Living Resource Conservation for Sustainable Development, IUCN-NDP-WWF. Internet: https://portals.iucn.org/library/efiles/ documents/WCS-004.pdf 1980 [Jun. 15, 2015].

[13] Internet: http://ulicaekologiczna.pl/zdrowy-styl-zycia/ slad-ekologiczny-\%E2\%80\%93-koszt-naszego-bycia-naziemi/, Jul.5, 2011 [Jul. 15, 2015]

[14] Living Planet Report: Biodiversity, biocapacity and better choices. Internet: http://www.wwf.de/ fileadmin/fm-wwf/Publikationen-PDF/ WWF_LPR_2012.pdf, 2012 [Jul. 15, 2015]

[15] Internet: www.footprintnetwork.org/atlas [Jul. 5, 2015]

dr inż. Anna Bluszcz

Silesian University of Technology, Faculty of Mining and Geology

Department of Mining Management and Safety Engineering

ul. Akademicka 2a, 44-100 Gliwice, POLAND

e-mail: anna.bluszcz@polsl.pl internetowej czasopisma.
The article in Polish language version available on the website of the journal 